\title{
Clay mineral composition and their sources for the fluvial sediments of Taiwanese rivers
}

\author{
LI ChuanShun $^{1}$, SHI XueFa ${ }^{1 *}$, KAO ShuhJi $^{2}$, CHEN MinTe $^{3}$, LIU YanGuang $^{1}$, FANG XiSheng $^{1}$, \\ LÜ HuaHua ${ }^{1}$, ZOU JianJun ${ }^{1}$, LIU ShengFa ${ }^{1}$ \& QIAO ShuQing ${ }^{1}$ \\ ${ }^{1}$ First Institute of Oceanography, State Oceanic Administration, Qingdao 266061, China; \\ ${ }^{2}$ Research Center for Environmental Changes, Academia Sinica, Taipei 11529, China; \\ ${ }^{3}$ Institute of Applied Geosciences, Taiwan Ocean University, Keelung 20224, China
}

Received April 6, 2011; accepted September 5, 2011; published online November 19, 2011

\begin{abstract}
Located at the collision boundary between the Philippine Sea Plate and the Eurasian Continental Plate, the island of Taiwan is generally recognized as an important example in the MARGINS Program Science Plan and "source-to-sink" research because of its high tectonic activity, heavy rainfall and unique geography. Large suspended sediment loads are transported to the adjacent ocean by Taiwanese rivers every year, making Taiwan an important source of sediments into the adjacent seas and a natural laboratory for studying the systemic movement of fluvial sediments from source to sink. A detailed study on the clay mineral composition of surface sediments collected from the drainage basins of 12 Taiwanese rivers using X-ray diffraction methods was conducted. Our results indicated that the clay mineral assemblages consisted dominantly of illite (approximately 73\%) and chlorite (approximately 24\%), with lesser abundances of kaolinite (approximately 3\%) and even lower levels of smectite from the Danshuei River sediments in northwestern Taiwan. The Jhuoshuei River sediments from western Taiwan contained clay mineral assemblages that consisted of illite (approximately 75\%) and chlorite (approximately 25\%), but they lacked kaolinite and smectite. In southwestern Taiwan, the clay mineral assemblages were dominated by illite (approximately 75\%) and chlorite (approximately $23 \%$ ), but had a low abundance of kaolinite (generally $<2 \%$ ) and no smectite. The clay mineral assemblages in eastern Taiwan are obviously different from those in western parts of the island. The most noticeable difference is that the average abundance of chlorite in the Hualien River from eastern Taiwan was the highest (approximately 48\%) of all the Taiwanese rivers. We concluded that, in general, the clay mineral assemblages in Taiwanese rivers were mainly composed of illite and chlorite with kaolinite and smectite being scarce, and these trends are different from those in China's mainland rivers. The clay mineral composition shown in this study was primarily determined by the properties of the bedrock, and the differential weathering intensities of the drainage area. The surface sediments in Taiwan's rivers showed a greater abundance of illite and chlorite because the outcropped rocks were mainly composed of Tertiary sedimentary rocks, especially sandstone, shale and slate, and show strong physical weathering. The relatively high relief and more abundant rainfall also caused the clay minerals in the fluvial sediments to be transported to the estuaries down rivers from the mountains and then delivered to the adjacent seas by currents and waves over a shorter time scale.
\end{abstract}

Taiwanese rivers, fluvial sediments, clay minerals, weathering, provenance

Citation: $\quad$ Li C S, Shi X F, Kao S J, et al. Clay mineral composition and their sources for the fluvial sediments of Taiwanese rivers. Chin Sci Bull, 2012, 57: 673-681, doi: 10.1007/s11434-011-4824-1

The island of Taiwan is located at the tectonic collision boundary between the Philippine Sea Plate and the Eurasian Continental Plate, resulting in a rapid mountain uplift rate of

*Corresponding author (email: xfshi@ fio.org.cn)
5-7 mm/a. Given its steep topographic gradients, less weatherresistant rocks (mainly composed of Tertiary metamorphic and sedimentary rocks), high tectonic activity, periodic typhoons and heavy rainfall, like that which is found in some regions of New Zealand and Papua New Guinea [1,2], Tai- 
wan is generally known to have one of the highest sediment yields in the world [3]. Based on previous measurements and estimates, Taiwanese rivers presently have annual discharges of approximately 180-380 Mt of sediment into the surrounding seas $[4,5]$, which indicates that Taiwan is an important sediment source for the region [6-8]. However, little work has been done on the clay mineral composition of fluvial sediment from Taiwanese rivers, which makes it difficult to trace the sediment origins and provenance, particularly of the more offshore sediments that are derived from the fluvial sources. Between January and August of 2010, we conducted a detailed investigation and sampling program for 12 rivers in Taiwan. They included the Gaoping, Zengwun, Jhuoshuei and Wu Rivers, along with the Dajia, Daan, Toucian and Danshuei Rivers all in western Taiwan and the Siouguluan, Hualien, Lanyang and Shuang Rivers in eastern Taiwan. In this study, our initial results for the clay mineral composition of the fluvial sediments and our analyses of their possible sources from these 12 Taiwanese rivers are shown.

\section{Geological and climatic settings}

Taiwan is one of the densest river-covered regions in Asia. There are approximately 150 rivers/streams/creeks in Taiwan and their overall length exceeds $42000 \mathrm{~km}$, with $1.17 \mathrm{~m} / \mathrm{km}^{2}$ for each river, on average. The high elevation of the Central Mountain Range serves as the major drainage divide for the entire island. The rivers in eastern Taiwan drain into the Pacific Ocean or the East China Sea, while those in the west drain into the Taiwan Strait or into the northern South China Sea. As the central dividing range inclines toward the east, the rivers in eastern Taiwan are generally shorter; with steeper slopes and have greater flows when in flood. For example, the longest river in western Taiwan, the Jhuoshuei River, is merely $186 \mathrm{~km}$ in length with a slope of $1 / 46$. In the dry season, the flow rate is so low that the bedrock is exposed, but during a flood, the peak flow can reach $10000 \mathrm{~m}^{3} / \mathrm{s}$ from a drainage area of approximately $3000 \mathrm{~km}^{2}$. Moreover, a flood carries huge amounts of sediment. The Jhuoshuei River during the 3-d typhoon period of Typhoon Herb in 1996 , for example, transported $\sim 130$ Mt of sediments into the Taiwan Strait [9] from one estimate, demonstrating the large transportation capacity for fluvial sediments of some Taiwanese rivers.

Taiwan is an island consisting primarily of Tertiary marine sedimentary outcrops. These rocks cover most of the western foothills and the alluvial plains west to the Chuchih Fault. The ridge (and the west wing of the Central Mountain Range) is composed of low-grade metamorphic mudstone called the "slate group" and is geologically independent from the Tananao metamorphic strata. The geological age of the slate groups ranges from the Eocene to early Miocene. The mineral composition of the slate groups indicates that they originated from detrital components of marine sedimentary rocks from the western side of the continent. The deformational and metamorphic degree of the slate group increases eastwards and transforms into low green schist metamorphic facies at the very eastern side of Taiwan. On the other hand, shallow marine sedimentary rocks of the Neogene age are distributed extensively along the western foothill regions of Taiwan, most abundantly on cross-bedded sandstone, siltstone and shale, with scattered limestone outcrops. The Coastal Mountain Range in the east consists mainly of sedimentary rocks as well as andesite agglomerate and tuff. Overall, sedimentary rocks occupy 55\% of the outcrop area of Taiwan Island, with primarily shale, mudstone and siltstone being present as well as (to a lesser degree) sandstone, with smaller amounts of conglomerate and breccia. Aside from these sedimentary rocks, along the longitudinal axis of the island, roughly between the Chuchih Fault and the Central Range, there are outcrops of lowgrade Tertiary aged metamorphic sedimentary rocks. The above two categories of sedimentary rocks occupy approximately $86 \%$ of the rocky outcrops in Taiwan, and the remaining $14 \%$ are principally Tertiary metamorphic rocks. The strata are, in general, outcropped in parallel with the longitudinal axis of the island, among which the Central Range and the Hsuehshan Range are metamorphic rocks. The piedmont and coastal plains around the island and the Coastal Range are composed primarily of sedimentary rocks. The igneous rocks of the island are mostly volcanic, with few intrusive origins. The volcanic rocks are distributed mainly in the Datun volcanoes, Keelung volcanoes, Coastal Range (andesite and quartz andesite) and Penghu Islands (basalt). Overall, Taiwan can be divided into three geological zones, namely, the Central Mountain Range zone, the western foothill zone and the eastern coastal range zone [10].

Since Taiwan is situated across the Tropic of Cancer, the climate is maritime sub-tropical with a mean annual temperature of $22^{\circ} \mathrm{C}\left(15-18^{\circ} \mathrm{C}\right.$ in Jan. and Feb.; $24-28^{\circ} \mathrm{C}$ in Jul. and Aug.) and has a mean annual precipitation of approximately $2515 \mathrm{~mm}$. Rainfall in Taiwan is abundant, with greater than $90 \times 10^{9} \mathrm{~m}^{3}$ annually but unevenly distributed in time and space. Mountainous areas receive 3000-5000 mm annually, while the plains get only approximately $1500 \mathrm{~mm}$. Over an annual cycle, on average, the majority of the rain falls in the wet season (May-Oct.) accounting for approximately $78 \%$ of the rainfall with less than $10 \%$ occurring in the dry season (Nov.-Apr.). Southern Taiwan sometimes receives even less rainfall in the dry season, resulting in severe droughts. In addition, tropical storms (typhoons) occur irregularly in the summer, bringing very heavy rainfall, which can produce severe floods. Statistics show that approximately 350 typhoons occurred in Taiwan between 1897 and 1998, with an average of 3-5 typhoons per year, resulting in more than 1000 heavy rainfall events in one century. 


\section{Materials and methods}

A set of 41 river surface sediment samples were collected downstream and at estuary sites from 12 major rivers in Taiwan, including 24 samples from 8 rivers in western Taiwan and 17 samples from 4 rivers in eastern Taiwan (Figure 1, Table 1). Considering that surface detrital/muddy sediments on the bottom of these rivers generally represent one of the components of suspended particles in river water [11], we collected sediment samples directly either on a river bank near the water or from the bottom of the river where the depth of the water was $<1 \mathrm{~m}$. The sampling sites were chosen downstream from the river and in an estuary so that the mineralogical and geochemical composition of the sediments would approximate the average composition of the suspended sediments from the entire drainage basin in each case. Fieldwork was carried out in January and in August of 2010. The sampling sites were chosen to avoid disturbance from activities such as riverbank transportation as well as pollution. To compare the mainland rivers in China, we also used clay mineral data from previous studies on the Yangtze River, Yellow River and Pearl River.

Surface sediments were ground and then sieved through a 250 -mesh (about $63 \mu \mathrm{m}$ pore size) nylon sieve. The finegrained components $(<63 \mu \mathrm{m})$ were used for clay mineral and geochemical elemental analyses; the coarse-grained components $(>63 \mu \mathrm{m})$ were used for the clastic mineral analyses. Clay mineral studies were performed on the $<2 \mu \mathrm{m}$ fraction, which was separated out based on conventional Stokes' settling velocity principles (after removing the carbonate and organic matter) with acetic acid (15\%) and hydrogen peroxide (10\%), respectively. Each sample was transferred to two slides by wet smearing. Samples were then air-dried prior to XRD analysis. First, one slide was measured directly after air-drying, and then measured again after ethylene-glycol salvation for $24 \mathrm{~h}$. Another slide was heated at $490^{\circ} \mathrm{C}$ for $2 \mathrm{~h}$ and then measured. The remaining samples were treated with $6 \mathrm{~mol} / \mathrm{L} \mathrm{HCl}$ and heated at $80^{\circ} \mathrm{C}$

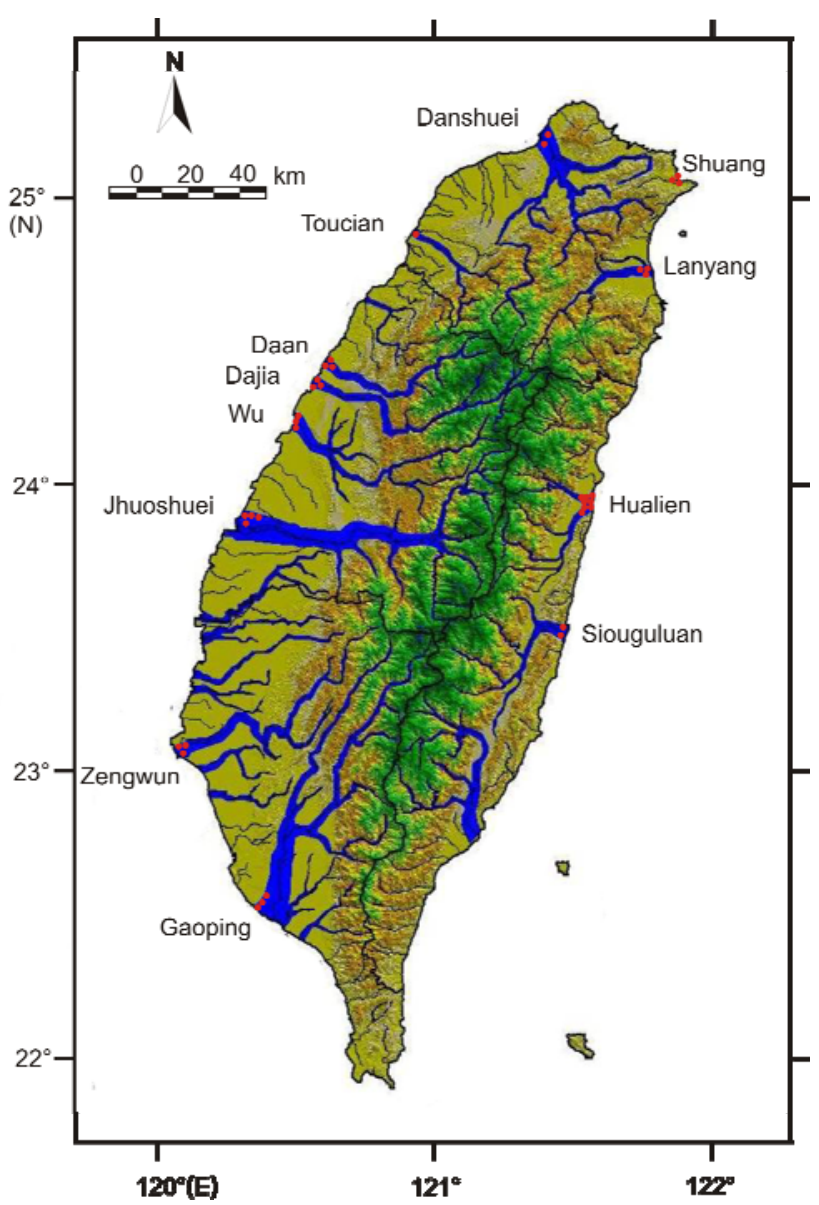

Figure 1 Map showing surface sediment sample collection points from the drainage basins of twelve primary rivers in Taiwan.

Table 1 Geographical information for the Taiwanese rivers

\begin{tabular}{|c|c|c|c|c|c|c|c|c|}
\hline River $^{\text {a) }}$ & Station & $\begin{array}{l}\text { Latitude } \\
\qquad\left({ }^{\circ} \mathrm{N}\right)\end{array}$ & $\begin{array}{l}\text { Longitude } \\
\left({ }^{\circ} \mathrm{E}\right)\end{array}$ & $\begin{array}{l}\text { Length } \\
(\mathrm{km})\end{array}$ & $\begin{array}{l}\text { Drainage area } \\
\qquad\left(\mathrm{km}^{2}\right)\end{array}$ & $\begin{array}{l}\text { Annual } \\
\text { rainfall } \\
(\mathrm{mm} / \mathrm{a})\end{array}$ & $\begin{array}{c}\text { Annual } \\
\text { runoff } \\
\left(10^{6} \mathrm{~m}^{3}\right) \\
\end{array}$ & $\begin{array}{c}\text { Suspended } \\
\text { sediment } \\
\text { discharge }(\mathrm{Mt} / \mathrm{a}) \\
\end{array}$ \\
\hline Danshuei & Kuandu Bridge & 25.131 & 121.452 & 158.87 & 2726 & 2939 & 7043.97 & 11.45 \\
\hline Toucian & JhongJheng Bridge & 24.785 & 121.057 & 63.03 & 566 & 2200 & 989.21 & 2.56 \\
\hline Daan & Daan River Bridge & 24.368 & 120.646 & 95.76 & 758 & 2300 & 1573.24 & 4.97 \\
\hline Dajia & Dajia Bridge & 24.314 & 120.605 & 140.21 & 1235 & 2200 & 2596.33 & 4.03 \\
\hline Jhuoshuei & West Sea Bridge & 23.834 & 120.289 & 186.4 & 3155 & 2200 & 6094.76 & 63.87 \\
\hline Zengwun & Zengwun Bridge & 23.156 & 120.339 & 138.47 & 1177 & 2300 & 2361.27 & 31 \\
\hline Gaoping & Wanda Bridge & 22.597 & 120.437 & 170.9 & 3256 & 2500 & 8455.33 & 35.61 \\
\hline Hualien & Hualien Bridge & 23.937 & 121.609 & 57.28 & 1507 & 2600 & 3809.26 & 20.61 \\
\hline Siouguluan & Changhong Bridge & 23.478 & 121.499 & 81.15 & 1790 & 2300 & 4179.02 & 19.97 \\
\hline Shuang & Crane Bridge & 25.023 & 121.936 & 26.81 & 132 & 3000 & - & 1.15 \\
\hline
\end{tabular}

a) Sources: Kao \& Milliman [12] and Taiwan Water Resources Agency of Taiwan. 
for $2 \mathrm{~h}$, and then transferred to a slide after removing the acid. Every ethylene-glycol salvation sample was measured twice, the first scanning was done from $3^{\circ}$ to $35^{\circ} 2 \theta$ with a step size of $0.02^{\circ}$, and the second scanning was done from $24^{\circ}$ to $26^{\circ} 2 \theta$ with a $0.01^{\circ}$ step. The latter was run as a slow scan to distinguish the 3.54/3.58 $\AA$ kaolinite/chlorite double peak. Clay minerals were identified by X-ray diffraction (XRD) using a D/max-2500 diffractometer with $\mathrm{CuK} \alpha$ radiation $(40 \mathrm{kV}$ and $100 \mathrm{~mA})$ in the laboratory of the First Institute of Oceanography, at the State Oceanic Administration of China.

Clay minerals were identified according to the position of the (001) series of basal reflections on the four XRD diagrams. Semi-quantitative estimation of peak areas of the basal reflection for the main clay mineral groups of smectite $(17 \AA)$, illite $(10 \AA)$, and kaolinite/chlorite (7 $\AA$ ) were carried out on the glycolated samples using Jade 5.0 software with empirical factors from Biscaye [13] and Petschick [14]. Relative clay mineral abundances are given in percentages. For consistency, all the clay mineralogical data referred to in this study was calculated based on the method, of Biscaye [13]. The illite crystallinity was calculated as the full width at half maximum (FWHM) of the illite $10 \AA$ peak, following Diekmann [15]. Generally, high values indicate poor crystallinities (highly degraded), whereas low values indicate good crystallinities (relatively unaltered). In this study, the following crystallinity categories (range of values) have been used for illite: very well crystalline $(<0.4)$; well crystalline (0.4-0.6); moderately crystalline (0.6-0.8); and poorly crystalline $(>0.8)$. Furthermore, the illite chemical index was estimated using a ratio for the $5 \AA$ and $10 \AA$ peak areas ratio for the ethylene-glycolated samples. Ratios above 0.5 indicate Al-rich illites, indicating that they were formed under strong hydrolysis. Ratios below 0.5 represent Fe-Mgrich illites (biotites and micas), which were determined from physically eroded, non-weathered rocks [15]. Both parameters were useful in tracing sediment sources and their transportation pathways.

\section{Results}

Qualitative analysis was carried out based on four XRD diagrams (Figure 2). We selected XRD diagrams based on samples from four rivers under different conditions for comparison. In the usual X-ray diagrams for all four rivers, there are obvious reflection peaks such as at $6.1^{\circ}, 8.7^{\circ}$, $12.4^{\circ}, 17.6^{\circ}, 18.7^{\circ}, 25.1^{\circ}$ and quartz $\left(26.5^{\circ}\right)$, and feldspar $\left(27.8^{\circ}\right)$. The $8.7^{\circ}$ and $17.6^{\circ}$ peaks are very high and remain unchanged after glycol-solvation, indicating the presence of illite. The illite peaks were enhanced after being heated to $490^{\circ} \mathrm{C}$ as the interstitial water was pulled out. The peak near $6.1^{\circ}$ was the first-class basal plane diffraction peak of chlorite, and this peak was separated into two peaks near $5.1^{\circ}$ and $6.1^{\circ}$ after glycol-solvation in the XRD diagrams for the
$\mathrm{Wu}$ and Hualien rivers but the $5.1^{\circ}$ peak disappeared completely after the $490^{\circ} \mathrm{C}$ heat treatment, indicating that the fluvial sediments from these two rivers contained a small amount of smectite. However, there was no smectite in the samples from the Gaoping River and Shuang River. There were $12.4^{\circ}$ and $24.8^{\circ}$ peaks in the sediment samples from the Shuang River and Wu River, and both peaks remained unchanged after glycol-solvation but become obviously weaker after heating at $490^{\circ} \mathrm{C}$, suggesting the existence of kaolinite in the fluvial sediments of these two rivers. In the samples from the Gaoping River and Hualien River, there was no $24.8^{\circ}$ peak, and after the second scanning, which was from $24^{\circ}$ to $26^{\circ} 2 \theta$ with a $0.01^{\circ}$ step, there was still no kaolinite peak. The $25.1^{\circ}$ peak disappeared nearly completely in the XRD diagrams of the hot $\mathrm{HCl}$-treated $\left(80^{\circ} \mathrm{C}\right)$ samples, indicating that there was no kaolinite in the samples from the Gaoping River and Hualien River. In all samples from these four rivers, there were $12.4^{\circ}$ and $25.1^{\circ}$ peaks that had not undergone significant changes after glycol-solvation but become obviously weaker after heating at $490^{\circ} \mathrm{C}$, indicating the existence of chlorite minerals.

The clay-sized fraction $(<2 \mu \mathrm{m})$ minerals from the Taiwanese rivers were mainly composed of two major clay mineral species, with lesser amounts of quartz and feldspar. Illite and chlorite were the dominant components of all these samples. Based on our XRD analysis, we calculated the percentages of the four clay mineral species present for every sample. The clay mineral assemblages in these Taiwanese rivers consisted mainly of illite $(52 \%-81 \%$, with an average of $71 \%)$ and chlorite $(13 \%-48 \%$, with an average of $26 \%$ ). Kaolinite was less abundant (with an average of $3 \%$ ) except for the samples from the Zengwun and Wu rivers in western Taiwan and from the Shuang River in the northeastern Taiwan. Smectite was scarce in all of these 12 rivers (Table 2). Illite was the most dominant clay mineral in the sediments, with an average abundance of more than $65 \%$, except for the Hualien River and the Siouguluan River. Chlorite was less abundant than the illite, with an average abundance of more than $20 \%$, with two exceptions (the Shuang River and the Daan River) with abundances of approximately $13 \%$ and $18 \%$, respectively. The chlorite percentage in eastern Taiwan was always higher than in western Taiwan. For example, chlorite abundances in the Hualien River and Siouguluan River were as high as $48 \%$ and $36 \%$, respectively, which was different from the clay mineral assemblages in sediments from the Yangtze and Yellow Rivers (Figure 3, Table 2). Compared with the Yangtze and Yellow Rivers, fluvial sediments in the Taiwanese rivers were more enriched in illite and chlorite, but relatively scarce in kaolinite and smectite. The smectite content was less than $1 \%$ in the Zengwun River, Wu River and Hualien River, and there was no smectite in the other rivers. Similarly, the kaolinitic percentages in the Wu River, Zengwun River and Shuang River were approximately 7\%, 8\% and $11 \%$, respectively. However, the average kaolinite percentages 

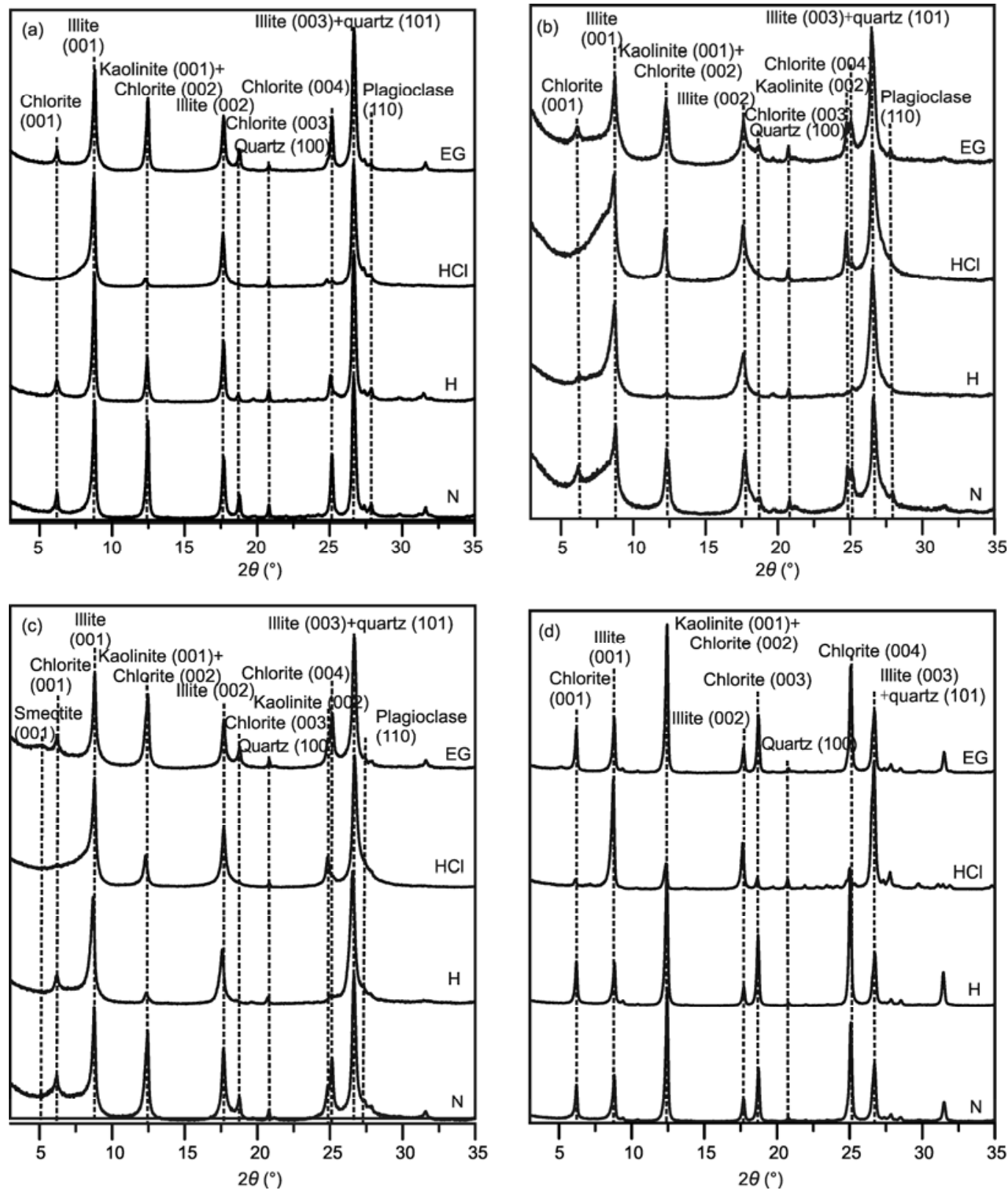

Figure 2 Multiple X-ray diffraction diagrams of typical samples from Taiwanese rivers drainage basins. (a) Gaoping River; (b) Shuang River; (c) Wu River; (d) Hualien River. The four curves represent glycolated (EG), hydrochloric acid treated $(\mathrm{HCl}), 490^{\circ} \mathrm{C}$ heated $(\mathrm{H})$, and normal diagrams $(\mathrm{N})$.

in the other rivers were less than $3 \%$ and virtually no kaolinite was found in the Hualien River, Lanyang River, Siouguluan River or Toucian River. The illite crystallinity varied in the range of $0.24^{\circ}-0.46^{\circ} \Delta 2 \theta$, with an average of $0.32^{\circ} \Delta 2 \theta$ in these rivers. Only samples from the Shuang River reached $0.47^{\circ} \Delta 2 \theta$; the illite crystallinity in the other rivers was less than $0.40^{\circ} \Delta 2 \theta$, indicating that the illite had the highest crystallinity due to the strong weathering environment in Taiwan. The illite chemistry index for the sediments from all the Taiwanese rivers varied between 0.40 and 0.63 , with an average of 0.49 , and the illite chemistry index in the eastern Taiwan was always smaller than in western Taiwan, indicating that the illite in Taiwan was mainly Fe-Mg rich and the chemical weathering in the west of Taiwan was stronger than that in eastern Taiwan.

\section{Discussions}

The clay mineral samples collected in this study were the weathering products of surface rocks and soil in the drainage areas. The weathering processes include both physical and chemical ones. Physical weathering causes the disintegration of rocks without a change in the chemical composition. The primary process for physical weathering is abrasion, by which clasts and other particles are reduced in size. 
Table 2 The clay mineral composition of various riverbeds

\begin{tabular}{|c|c|c|c|c|c|c|c|}
\hline River & $\begin{array}{l}\text { Sample } \\
\text { number }\end{array}$ & $\begin{array}{c}\text { Smectite } \\
(\%)\end{array}$ & $\begin{array}{l}\text { Illite } \\
(\%)\end{array}$ & $\begin{array}{c}\text { Kaolinite } \\
(\%)\end{array}$ & $\begin{array}{c}\text { Chlorite } \\
(\%)\end{array}$ & $\begin{array}{l}\text { Illite crystallinity } \\
\left({ }^{\circ} \Delta 2 \theta\right)\end{array}$ & $\begin{array}{l}\text { Illite chemistry } \\
\text { index }\end{array}$ \\
\hline Daan & 3 & 0 & 81 & 1 & 18 & 0.35 & 0.56 \\
\hline Dajia & 3 & 0 & 73 & 2 & 25 & 0.29 & 0.54 \\
\hline Danshuei & 2 & 0 & 73 & 3 & 24 & 0.34 & 0.49 \\
\hline Toucian & 2 & 0 & 66 & 0 & 34 & 0.37 & 0.43 \\
\hline Jhuoshuei & 4 & 0 & 75 & 1 & 24 & 0.27 & 0.40 \\
\hline Gaoping & 4 & 0 & 75 & 2 & 23 & 0.30 & 0.47 \\
\hline Shuang & 3 & 0 & 76 & 11 & 13 & 0.46 & 0.63 \\
\hline Zengwun & 3 & 0 & 72 & 8 & 20 & 0.36 & 0.49 \\
\hline $\mathrm{Wu}$ & 3 & 0 & 69 & 7 & 24 & 0.31 & 0.56 \\
\hline Hualien & 8 & 0 & 52 & 0 & 48 & 0.24 & 0.46 \\
\hline Lanyang & 3 & 0 & 77 & 0 & 23 & 0.34 & 0.48 \\
\hline Siouguluan & 3 & 0 & 64 & 0 & 36 & 0.25 & 0.44 \\
\hline Jhuoshuei $^{\text {a) }}$ & 3 & 0 & 69 & 1 & 30 & 0.20 & 0.30 \\
\hline SW Taiwan rivers ${ }^{\text {b) }}$ & 19 & 0 & 71 & 1 & 28 & 0.16 & 0.33 \\
\hline Lanyang ${ }^{c)}$ & 6 & 0 & 78 & 6 & 17 & 0.30 & 0.45 \\
\hline Jhuoshuei $^{\text {d) }}$ & 7 & $0 \pm 0$ & $71 \pm 1$ & $1 \pm 1$ & $28 \pm 1$ & - & - \\
\hline Yangtze $^{\mathrm{e})}$ & & 6 & 66 & 16 & 12 & - & - \\
\hline Yellow $^{\text {e) }}$ & & 12 & 62 & 10 & 16 & - & - \\
\hline Pearl $^{\mathrm{f}}$ & 47 & 1 & 42 & 36 & 21 & 0.28 & 0.60 \\
\hline ECS inner shelf mud ${ }^{\mathrm{g})}$ & 7 & 3 & 77 & 9 & 12 & - & - \\
\hline SW Taiwan shelf ${ }^{\text {b) }}$ & 11 & 0 & 74 & 0 & 26 & 0.16 & 0.36 \\
\hline
\end{tabular}

a) Wan et al. [16]; b) Liu et al. [7]; c) Cheng [17]; d) Xu et al. [18] and Liu et al. [19]; e) Yang et al. [20]; f) Liu et al. [21]; g) Liu et al. [22]. ECS means the East China Sea.

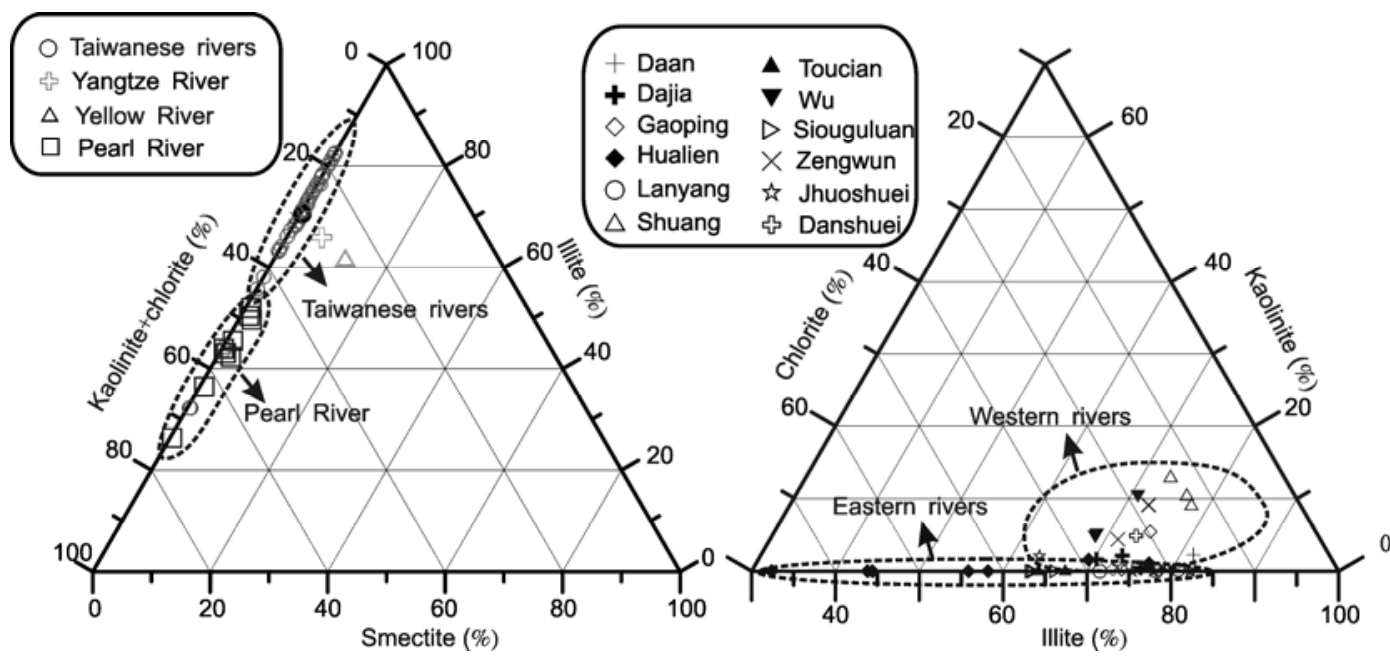

Figure 3 Clay mineral assemblages in surface sediments from Taiwanese rivers, and the Yangtze River, Yellow River [20] and Pearl River [21].

Chemical weathering changes the composition of rocks by hydrolyzing the minerals, which in turn, produces new minerals. The clastic clay minerals (including feldspar) are the most common weathering products. As an important group of minerals and the most common products of chemical weathering, clay minerals are the main constituents of fine- grained sedimentary rocks such as shale, mudstone, siltstone and fine-grained metamorphic slate and phyllite. As the main constituent of ancient mudstones and shales, illite and chlorite are formed by the alteration of minerals like muscovite and feldspar. Kaolinite is formed by weathering or the hydrothermal alteration of aluminosilicate minerals, 
and smectite is the main constituent of Fe-Mg aluminosilicate minerals [23]. Therefore, clay minerals are produced by the transformation of parent rocks by physical weathering without chemical modification of the minerals, and/or by chemical weathering causing a transformation of the primary minerals with the formation of secondary clay minerals. The intensity of the weathering depends on the composition of the parent rocks, the climate, water, and the biological activity. Clay minerals can be eroded, transported and deposited by water and the wind. The formation of soils and clay minerals is influenced by climate, vegetation and fauna, lithology, landforms, interstitial water, time, and human activity. Therefore, clay minerals provide clues to their parent rocks and to the climatic conditions during the process of their formation.

The climate in Taiwan is warm and humid, and the vegetation has a closed canopy, an environment that helps to accelerate chemical weathering. At the same time, high topographies, frequent seismic and typhoon activities, and related storm-triggered landslides leave the surface rocks with insufficient time to undergo chemical weathering. Therefore, relatively high physical versus chemical denudation rates occur on this oceanic island [24]. The clay mineral assemblages in Taiwan are determined by the composition of the bedrock. Most of the island is composed of Tertiary metamorphic and sedimentary rocks such as sandstone, shale, slate and phyllite [10]. Illite minerals are mainly formed in the mudstone areas of southern Taiwan, the argillite and slate areas of the Hsuehshan Range and Central Mountain Range, while chlorite is mainly formed from the schist, amphibolite, gneiss and mudstones of the Central Mountain Range [17]. The twelve rivers studied here all originate in the Central Mountain Range, so the clay mineral assemblages of the fluvial sediments in these rivers mainly consist of illite (average $71 \%$ ) and chlorite (average $26 \%$, Figure 3). In western Taiwan, the most important three rivers, the Jhuoshuei, Gaoping and Danshuei, have average illite percentages of $75 \%, 75 \%$ and $73 \%$, respectively and the average chlorite content in these three rivers was $25 \%, 23 \%$ and $24 \%$, respectively. The clay mineral assemblages present in these Taiwanese rivers indicate that the weathering products of the rocks and soil are transported to the estuary by the rivers first, and then delivered to the adjacent seas by currents and waves; this is consistent with other previous studies on the clay mineral assemblages of Taiwanese rivers and transport of surface sediments $[7,8$, 17-19,22]. In addition, the runoff fluxes in these rivers have noticeable seasonal variations. During the sampling in January, 2010 (the dry season in Taiwan), the runoff was so low that the bedrock was exposed with gravels (some with diameters greater than $1 \mathrm{~m}$ ) in the western rivers such as the Daan and Dajia. However, during the flood season, the typhoons and heavy rainfall often carried huge amounts of sediment. Therefore, we believe that the samples studied here are mainly from tremendously high loadings of sus- pended sediments that are transported during the flood seasons [9,25].

The clay mineral assemblages in the Hualien River and Siouguluan River (with their more abundant chlorite from eastern Taiwan) were significantly different from the other rivers (Figure 2, Table 2). As the most abundant mineral in all these Taiwanese rivers, the chlorite content in the 8 samples from the Hualien River varied between $67 \%$ and $22 \%$, with an average of $48 \%$. Moreover, in the Siouguluan River (which lies to the south of the Hualien River), the chlorite percentage of the three fluvial sediments was $36 \%, 37 \%$ and $34 \%$, respectively, with an average of $36 \%$. In both rivers, there was almost no kaolinite and even less smectite. The average illite percentage in the Hualien River sediment was $52 \%$, with the lowest being 32\%. In the Siouguluan River, the average percentage of illite present was $64 \%$. The abundant chlorite in the above two rivers in eastern Taiwan was closely correlated with the type of local bedrock in the catchment. The Hualien River, originating from an offshoot of the Central Mountain Range in Hualien County, had bedrock that was mainly composed of slate and phyllite, with inter-layered metamorphic sandstone [10]. These rocks can produce abundant chlorite mineral after strong physical weathering that can be transported to the estuary area by the Hualien River. In addition, the illite crystallinity from the Hualien River had the lowest values (the average being $0.24^{\circ} \Delta 2 \theta$ ) of all Taiwanese rivers, indicating that the physical weathering in the Hualien River system plays a more important role. As the largest river in eastern Taiwan, the Siouguluan River originates from the southern side of Siouguluan Mountain and drains through the Tananao schist and green schist bedrock areas. The average topographic gradient of the Siouguluan River is approximately $1 / 34$, and there are frequent typhoons and heavy rainfall events in the drainage area every year, making the fluvial sediments in eastern Taiwan rich in illite and chlorite minerals, which are produced from the intensive physical weathering of the bedrock and soil. Our results are consistent with a previous study on the clay mineralogy of Pliocene-Pleistocene mudstone in eastern Taiwan, in that clay minerals are mainly detrital illite and chlorite, which are derived from the adjacent metamorphic orogeny, rather than being authigenic products of in situ burial metamorphism [26].

When there are high percentages of illite and chlorite present, there is also abundant kaolinite where there is strong chemical weathering. For example, in the mountains 1700-2200 $\mathrm{m}$ above sea level in eastern Taiwan, illite and kaolinite are the major minerals present in well-drained soils [27]. But these kaolinite-rich sediments accumulate mainly in mountain lakes, from which they are protected from being transported to the adjacent seas by rivers. For the Wu River and Zengwun River in western Taiwan and the Shuang River in northeastern Taiwan, sediment samples have average kaolinitic contents of $7 \%, 8 \%$ and $11 \%$, respectively, indicating that some of these river sediments are 
the products of strong chemical weathering. During our field sampling, we found that there was some yellow mud in these three rivers, which was different from the other rivers, which had gray sediments. Moreover, the clay mineral assemblages of the small Shuang River in northeastern Taiwan were very different from that of the neighboring Lanyang River. The average percentage of kaolinite in the Shuang River was $11 \%$ and the percentage of chlorite was also lower than that in the Lanyang River. The illite crystallinity of the Shuang River was $0.47^{\circ} \Delta 2 \theta$ on average, which was the highest value for all the twelve rivers, indicating that the Shuang River and the nearby Lanyang River had different sediment sources. The Shuang River is a small river with a length of only $27 \mathrm{~km}$, and the gradient is relatively gentle from upstream to downstream. The chemical weathering and physical erosion present are strong in the river basins, resulting in fluvial sediments that are different mineralogically from the other rivers.

Taiwan lies in a subtropical area with a warm and humid climate. It has among the highest rates of soil erosion in the world, with $1365 \mathrm{mg} \mathrm{cm}^{-2} \mathrm{a}^{-1}$ because of the active tectonics, frequent typhoons and heavy rainfall. The high erosion rate of the exposed rocks protects them from strong, long lasting chemical weathering. The clay mineral assemblages studied here are mainly composed of illite and chlorite, which are products of physical weathering. The illite chemistry index in these clay samples was significantly lower than that of the Pearl River [21], and in western Taiwan (which was higher than that in the east of Taiwan) (Figure 4), indicating that the chemical weathering intensity was greater in western Taiwan. As the central dividing range inclines to the east, the eastern rivers are generally shorter. In addition, due to more frequent typhoons and heavy rainfall, the eastern part of Taiwan generally undergoes more intensive physical weathering, while chemical weathering is diminished. In this study, however, we found that the Shuang River in northeastern Taiwan was an exceptional case (Figure 4).

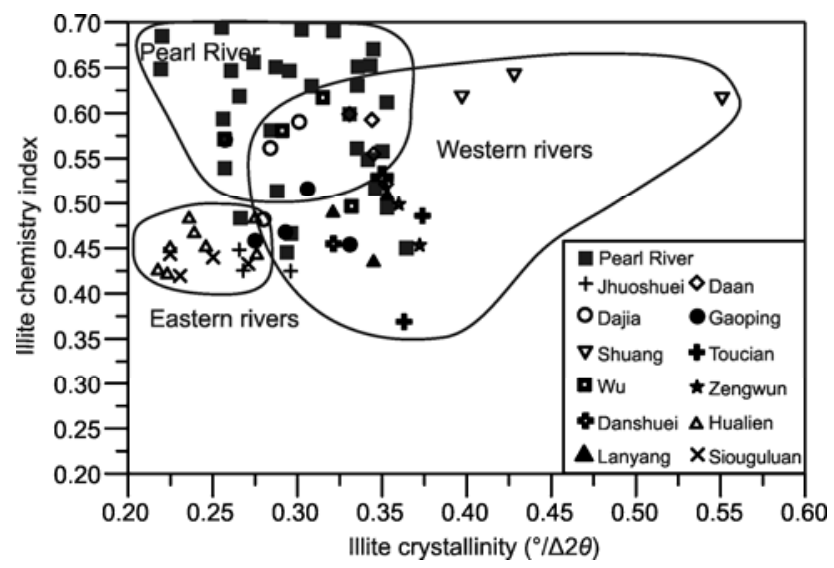

Figure 4 Correlations of the illite chemistry index with the illite crystallinity of surface sediments from the western and eastern rivers of Taiwan and the Pearl River [21].

\section{Conclusions}

Based on detailed clay mineral analysis of the surface sediments from several Taiwanese rivers, combined with information about the bedrock and weathering processes in Taiwan, we make the following conclusions from our study:

The clay mineral assemblages of the fluvial sediments in Taiwan consisted mainly of illite $(52 \%-81 \%$, average $71 \%)$ and chlorite (13\%-48\%, average $26 \%$ ); kaolinite and smectite were scarce and only found in one river. For the three major rivers, the Jhuoshuei, Gaoping and Danshuei in western Taiwan, the average illite percentages were $75 \%, 75 \%$ and $73 \%$, respectively, while the average percentages of chlorite were $25 \%, 23 \%$ and $24 \%$, respectively. In eastern Taiwan, the clay mineral assemblages were different from the western assemblages; for example, the percentages of chlorite in the Hualien and Siouguluan Rivers were $48 \%$ and $36 \%$, respectively. Compared with the rivers in mainland China (such as the Pearl River), the Taiwanese rivers had almost no smectite and very low kaolinite percentages.

The illite and chlorite abundance in the fluvial sediments from the Taiwanese rivers were mainly determined by the tectonic, bedrock and weathering conditions in Taiwan. Given its high relief, steep topographic gradients, soft and more erodible rocks (composed mainly of Tertiary metamorphic and sedimentary rocks), frequent earthquakes, and periodic typhoons and heavy rainfall, Taiwan has a geological setting that produces abundant illite and chloritic minerals as the major products of physical weathering and these are the minerals that ultimately end up in the surrounding seas.

We would like to thank Dr. Pai-Sen Yu from Taiwan Ocean University for his assistance with fieldwork and useful discussions, and Shiming Wan from the Institute of Oceanology, Chinese Academy of Sciences and Jianguo Liu from the South China Sea Institute of Oceanology, Chinese Academy of Sciences for their technical help and helpful discussions. We especially thank two anonymous reviewers and an expert on the Editorial Board for their constructive and detailed reviews of the early version of this paper. This work was supported by the National Natural Science Foundation of China (41006037), the Young Marine Science Foundation, State Oceanic Administration of China (2011309), Chinese Coastal Ocean Investigation and Research Project (908-ZC-I-05) and the Special Basic Research Fund for Central Public Research Institutes First Institute of Oceanography, State Oceanic Administration (GY02-2011G28).

1 Pickup G, Higgins R J, Warner R F. Erosion and sediment yield in Fly River drainage basins, Papua New Guinea. Inter Assoc Sci Hydrol Publ, 1981, 132: 438-456

2 Berryman K, Marden M, Eden D N, et al. Tectonic and paleoclimatic significance of Quaternary river terraces of the Waipaoa River, East Coast, North Island, New Zealand. New Zeal J Geol Geop, 2000, 43: 229-245

3 Li Y H. Denudation of Taiwan Island since the Pliocene epoch. J Geol, 1976, 4: 105-107

4 Dadson S J. Links between erosion, runoff variability and seismicity in the Taiwan orogen. Nature, 2003, 426: 648-651

5 Kao S J, Horing C S, Hsu S C, et al. Enhanced deepwater circulation 
and shift of sedimentary organic matter oxidation pathway in the Okinawa Trough since the Holocene. Geophys Res Lett, 2005, 32: 1-4

6 Diekmann B, Hofmann J, Henrich R, et al. Detrital sediment supply in the southern Okinawa Trough and its relation to sea-level and $\mathrm{Ku}-$ roshio dynamics during the late Quaternary. Mar Geol, 2008, 255: 83-95

7 Liu Z, Tuo S, Colin C, et al. Detrital fine-grained sediment contribution from Taiwan to the northern South China Sea and its relation to regional ocean circulation. Mar Geol, 2008, 255: 149-155

8 Wan S, Li A, Clift P D, et al. Increased contribution of terrigenous supply from Taiwan to the northern South China Sea since $3 \mathrm{Ma}$. Mar Geol, 2010, 278: 115-121

9 Kao S J, Jan S, Hsu S C, et al. Sediment budget in the Taiwan Strait with high fluvial sediment inputs from mountainous rivers: New observations and synthesis. Terr Atmos Ocean Sci, 2009, 19: 525-546

10 Chen P Y. Geology of Taiwan (in Chinese). Taipei: Applied Geology Association of Taiwan, 2008

11 Liu Z, Zhao Y, Colin C, et al. Chemical weathering in Luzon, Philippines from clay mineralogy and major-element geochemistry of river sediments. Appl Geochem, 2009, 24: 2195-2205

12 Kao S J, Milliman J D. Water and sediment discharge from small mountainous rivers, Taiwan: The roles of lithology, episodic events, and human activities. J Geol, 2008, 116: 431-448

13 Biscaye P E. Mineralogy and sedimentation of recent deep-sea clay in the Atlantic Ocean and adjacent seas and oceans. Geol Soc Am Bull, 1965, 76: 803-832

14 Petschick R, Kuhn G, Gingele F. Clay mineral distribution in surface sediments of the South Atlantic: Sources, transport, and relation to oceanography. Mar Geol, 1996, 130: 203-229

15 Diekmann B, Wopfner H. Petrographic and diagenetic signatures of climatic change in peri- and postglacial Karoo Sediments of SW Tanzania. Palaeogeogr Palaeoclimatol Palaeoecol, 1996, 125: 5-25

16 Wan S, Li A, Clift P D, et al. Development of the East Asian monsoon: Mineralogical and sedimentologic records in the northern South
China Sea since 20 Ma. Palaeogeogr Palaeoclimatol Palaeoecol, 2007, 254: 561-582

17 Cheng C J. Clay mineral distribution in surface sediments of the southern Okinawa Trough (in Chinese). M.S. Thesis. Taipei: Institute of Oceanography, Taiwan University, 2008

18 Xu K H, Milliman J D, Li A C, et al. Yangtze-and Taiwan-derived sediments on the inner shelf of East China Sea. Cont Shelf Res, 2009, 29: 2240-2256

19 Liu J P, Liu C S, Xu K H, et al. Flux and fate of small Mountainous Rivers derived sediments into the Taiwan Strait. Mar Geol, 2008, 256: 65-76

20 Yang S Y, Jung H S, Lim D, et al. A review on the provenance discrimination of sediments in the Yellow Sea. Earth-Sci Rev, 2003, 63: 93-120

21 Liu Z F, Colin C, Huang W, et al. Clay minerals in surface sediments of the Pearl River drainage basin and their contribution to the South China Sea (in Chinese). Chin Sci Bull (Chin Ver), 2007, 52: 11011111

22 Liu J P, Li A C, Xu K H, et al. Sedimentary features of the Yangtze River-derived along-shelf clinoform deposit in the East China Sea. Cont Shelf Res, 2006, 26: 2141-2156

23 Chamley H. Clay Sedimentology. Berlin: Springer, 1989. 623

24 Selvaraj K, Chen C T A. Moderate chemical weathering of subtropical Taiwan: Constraints from solid-phase geochemistry of sediments and sedimentary rocks. J Geol, 2006, 114: 101-116

25 Milliman J D, Lin S W, Kao S J, et al. Short-term Changes in Seafloor Character due to Flood-Derived Hyperpycnal Discharge: Typhoon Mindulle, Taiwan, July 2004. Geology, 2007, 35: 779-782

26 Dorsey R J, Buchovecky E J, Lundberg N. Clay mineralogy of Pliocene-Pleistocene mudstones, eastern Taiwan combined effects of burial diagenesis and provenance unroofing. Geology, 1988, 16: 944-947

27 Pai C W, Wang M K, Chiu C Y. Clay mineralogical characterization of a toposequence of perhumid subalpine forest soils in northeastern Taiwan. Geoderma, 2007, 138: 177-184

Open Access This article is distributed under the terms of the Creative Commons Attribution License which permits any use, distribution, and reproduction in any medium, provided the original author(s) and source are credited. 